\title{
PENGARUH KOMPETENSI BERBAHASA ASING DAN PENGORGANISASIAN DALAM MENUNJANG KARIR DIBIDANG PUBLIC RELATIONS
}

\section{EFFECT OF FOREIGN LANGUAGE COMPETENCY AND ORGANIZATION IN SUPPORTING CAREER IN PUBLIC RELATIONS}

\author{
IA Yani1a, IA Ratnamulyani², AA Kusumadinata ${ }^{3 a}$ \\ Program studi Ilmu Komunikasi, Fakultas Ilmu Sosial Dan Ilmu Politik, \\ Universitas Djuanda Bogor \\ Jl. Tol Ciawi No 1 Kotak Pos 35 Bogor 16740 \\ “Korespondensi: IA Yani, Email: Indriandriani66@gmail.com \\ AA Kusumadinata, Email: alialamsyahkusumadinata@gmail.com
}

(Diterima: 30-12-2017; Ditelaah: 03-01-2018 ; Disetujui: 05 -02-2018)

\begin{abstract}
This study focuses on foreign language skills that can support a career in the field of public relations. with the ability of foreign languages will open many opportunities to get a good job in multinational company as well as expand the association in the world international because foreign languages are languages that are generally useful to be able to compete in the era of globalization. This research aims to (1) Explain how influence of foreign language competence can support careers in public relations. (2) Explain the influence of organize public relations can encourage career in public relations. (3) Analyzing influences between foreign language ability and ability to organize public relations in them. This research uses quantitative research method. The results of this study are foreign language skills that can support careers in the field of public relations and organizing in foreign languages can be establish good relationships with various communities, customers from various companies or organizations.
\end{abstract}

Keywords: Foreign Language, Public Speaking, Public Relations

\begin{abstract}
ABSTRAK
Penelitian ini memfokuskan pada kemampuan berbahasa asing yang dapat menunjang karir dibidang public relations dengan kemampuan bahasa asing akan terbuka banyak kesempatan untuk memperoleh pekerjaan yang baik di perusahaan multinasional serta untuk memperluas pergaulan di dunia internasional karena bahasa asing merupakan bahasa yang secara umum bermanfaat untuk dapat bersaing di era globalisasi. Penelitian ini bertujuan untuk (1) mendeskripsikan bagaimana pengaruh kompetensi berbahasa asing dapat menunjang karir dibidang public relation. (2) mendeskripsikan pengaruh pengorganisasi public relation dapat menujang karir dibidang public relations. (3) menganalisis pengaruh antara kemampuan bahasa asing dan kemampuan pengorganisasian public relation terhadap tugas public relations. penelitian ini menggunakan metode penelitian kuantitatif. Hasil dari penelitian ini adalah kemampuan berbahasa asing dapat menunjang karir dibidang public relations dan pengorganisasian dalam berbahasa asing dapat menjalin hubungan baik dengan berbagai komunitas, pelanggan dari berbagai perusahaan atau organisasi.
\end{abstract}

Kata Kunci : Bahasa Asing. Public Speaking, Public Relations

IA Yani, IA Ratnamulyani, AA Kusumadinata. 2018. Pengaruh Kompetensi Berbahasa Asing dan Pengorganisasian $P R$ dalam Menunjang Karir di bidang Public Relation. Jurnal Komunikatio: 1-12. 


\section{PENDAHULUAN}

Peranan bahasa asing sangatlah diperlukan dalam mengusai teknologi komunikasi maupun dalam berinteraksi secara langsung. Dengan kemampuan bahasa asing yang baik, akan terbuka banyak kesempatan untuk memperoleh pekerjaan yang baik di Perusahaan Multinasional yang memang mensyaratkan kemampuan bahasa asing yang baik, untuk memperluas pergaulan di Dunia Internasional karena bahasa asing merupakan bahasa yang secara umum bermanfaat untuk dapat bersaing di Era Globalisasi. Bagi pengalaman peneliti untuk menguasai bahasa asing tidak lah mudah dan bisa dikuasai secara cepat, namun membutuhkan berbagai tahapan-tahapan untuk sampai pada tahap menguasai, apalagi di era seperti ini mampu berbicara didepan umum dengan baik dan benar sudah menjadi bagian dari gaya hidup seseorang, sudah saatnya setiap orang yang ingin meningkatkan kualitas hidup, meningkatkan karir, meraih sukses yang lebih tinggi, trampil berbicara didepan umum dan lain sebagainya yang didasarkan oleh kempuan berbahasa asing.

Bila seseorang dapat berbahasa asing, maka orang itu dapat berbicara dengan lebih dari 1,6 miliar orang di seluruh dunia. Itu bukan jumlah teman yang sedikit tentunya, satu di antara empat orang di dunia berbicara paling tidak sedikit menggunakan bahasa asing, dan jumlah yang belajar terus akan bertambah. Misalnya, di Cina sendiri, jumlah orang yang belajar bahasa Inggris telah melampaui jumlah seluruh penduduk Amerika Serikat. Sinaga (2010), bila kalian menguasai bahasa asing, maka kalian dapat chatting secara online, menulis surat dan berkeliling dunia dalam menggunakan satu bahasa yaitu menggunakan bahasa.asing. Hal ini telah ditunjukkan dengan peraturan pemerintah yang menjadikan mata pelajaran bahasa Asing sebagai mata pelajaran wajib untuk dipelajari siswa dari sekolah dasar hingga jenjang SMA. Bahkan di level pendidikan tinggi, seluruh program studi pasti memberikan mata kuliah Bahasa Asing untuk 1 atau 2 semester meskipun disiplin ilmu yang diambil tidak berkaitan dengan Bahasa Asing. Hal tersebut menunjukkan betapa pentingnya penguasaan bahasa asing, khususnya bahasa Inggris sebagai salah satu pengantar kesuksesan bidang akademik seseorang maupun untuk menunjang karir di dunia kerja (Sinaga 2010).

Peneliti sebelelumnya yang dilakukan oleh Mambaunisa (2014) menunjukan bahwa prestasi belajar siswa dipengaruhi oleh kemampuan berbahasa sebesar 50,41\%. Dan sisanya 40.59\% dipengaruhi oleh faktor lain, baik intern maupun ekstren dari siswa. Sama halnya dengan tugas seorang Public Speaking selain menyampaikan ide kepada audiens dan ide tersebut berpotensi untuk mempengaruhi tindakan audiens. Untuk itu, sangat diperlukan persiapan yang optimal sebelum melakukan presentasi di depan audiens. Strategi dan persiapan tersebut menurut pengalaman dilapangan dalam menjadi Public Speaking yaitu: Pengenalan audiens, Pengenalan audiens dapat membekali kita dalam memilih bahan, menyusun, dan menyajikannya dengan strategi yang tepat. Menurut Gunadi (1998), Public Speaking sebagai sebuah bentuk komunikasi yang dilakukan secara lisan tentang suat hal atau topik dihadapan banyak orang, tujuannya adalah untuk mempengaruhi, merubah opini, mengajar, mendidik, memberi pembelajaran secara jelas serta informasi kepada masyarakat tertentu pada suatu tempat tertentu.

Saat ini, di Indonesia pembelajaran Bahasa Asing telah dimulai sejak SD, bahkan di beberapa taman kanak-kanak TK sudah mulai diperkenalkan walaupun masih sangat sederhana. Namun, menurut penelitian Hastuti dan Oswari (2008) dari tahun ketahun keberhasilan pembelajaran 
Bahasa Asing khususnya Bahasa Inggris di SMA masih belum memuaskan para orang tua, profesional dan dosen ketika ia memasuki bangku perkuliahan. Kondisi pembelajaran Bahasa Inggris yang ada sekarang ini belum bisa menghasilkan mahasiswa yang memiliki kemampuan Bahasa Inggris yang baik. Melihat kenyataan bahwa kemampuan Bahasa Inggris siswa dan mahasiswa yang masih rendah tersebut, maka difasilitasi oleh beberapa orang yang memiliki jiwa bisnis dengan mendirikan kursus-kursus bahasa Inggris. Akan tetapi, biaya kursus tersebut tergolong mahal. Salah satu kendala yang paling menyolok dari sumberdaya manusia kita adalah minimnya penguasaan bahasa asing seperti yang dikatakan penelitian sebelumnya Hasan (2006) bahwa penguasaan bahasa asing menjadi prasyarat mutlak untuk mengakses sumber informasi mutakhir yang banyak ditulis melalui bahasa-bahasa tersebut. Hal tersebut terjadi disamping mutu sumberdaya manusia pengelola pendidikan kurang memadai juga karena sistem pengelolaan pengajaran yang tidak diorientasikan pada penguasaan bahasa asing tersebut. Penguasaan siswa terhadap bahasa asing--dalam batas tertentu--lebih disebabkan oleh usahanya sendiri (belajar mandiri).

Oleh karena itu penelitian ini bertujuan :

1. mendeskripsikan bagaimana pengaruh kompetensi berbahasa asing dapat menunjang karir dibidang public relation.

2. Mendeskripsikan pengaruh pengorganisasi public relations dapat menujang karir dibidang public relations.

3. Menganalisis pengaruh antara kemampuan bahasa asing dan kemampuan pengorganisasian public relations terhadap tugas public relations.

\section{Tinjauan Teori}

\section{Fungsi Public Relations}

Fungsi Public Relations Menurut Rumanti (2009) pada dasarnya fungsi Public Realitions adalah : (1) Kegiatan yang bertujuan untuk memperoleh goodwill, kepercayaan, saling adanya pengertian dan citra yag baik dari publik. (2) Memiliki sasaran untuk menciptakan opini publik yang bisa diterima dan menguntungkan semua pihak. (3) Unsur penting dalam manajemen guna mencapai tujuan yang spesifik, sesuai harapan publik, tetapi merupakan kekhasan organisasi atau perusahaan. Sangat penting bagaimana organisasi memiliki warna, budaya, citra, dan suasana yang kondusif, peningkatan kinerja dan produktivitas bisa dicapai secara optimal. (4) Upaya menciptakan hubungan yang harmonis antara organisasi atau perusahaan dengan publiknya, internal atau eksternal melalui proses timbal balik, sekaligus menciptakan opini publik sebagai efeknya, yang sangat berguna sebagai input bagi organisasi yang bersangkutan

\section{Kegiatan Public Relations}

Public Relations mempunyai banyak peran penting, salah satu peran utama Public Relaiions adalah sebagai komunikator perusahaan, lembaga, organisasi, atau perorangan yang diwakilinya oleh publiknya, baik internal maupun eksternal. Menurut H. Fayol dalam (Ruslan 2005), mengemukakan beberapa kegiatan Public Relations, antara lain : (1) Membangun citra dan identitas perusahaan Building corporate image and identity. Kegiatan membangun citra dan identitas terbagi atas: (2) Menghadapi krisis yakni menangani keluhan (complaint) dan menghadapi krisis yang terjadi dalam membentuk manajemen krisis dan Public Relations Recovery of Image, yang bertugas memperbaiki lost of image dan damage. (3) Promosi Masalah Kemasyarakatan (Promotion of Public Causes) Kegiatan mempromosikan masalah kemasyarakatan ini terbagi atas: 
Ryanto (2011) menjelaskan pentingnya berbahasa Asing ketika kita mulai memasuki duni kerja, khususnya bagi setiap orang yang nantinya akan bekerja dilingkup komunikasi seperti Advertising, Public Relations dan Jurnalistik. Kefasihan dalam berbahasa Asing di dalam dunia kerja menjadi nilai tambah bagi setiap orang.

1. Advertising, kemampuan berbahasa Asing juga sangat diperlukan untuk bersaing di dunia Internasional. Untuk iklan yang berlaku secara global atau dalam skala Internasional, tagline atau kata-kata yang digunakan dalam iklan tersebut harus menggunakan bahasa Asing. Oleh karena itu seseorang yang bekerja di bidang advertising juga memerlukan kemampuan dalam berbahasa Asing.

2. Public Relations Officer. Seorang Public Relations Officer (PRO) tentunya harus bisa menjalin hubungan yang baik dengan banyak orang dari berbagai belahan dunia dan harus bisa bersikap sopan dan bertutur kata yang baik, karena pekerjaan seorang PRO tentunya berhubungan dengan banyak orang. Seorang PRO harus bisa memiliki kemampuan fasih dalam berbahasa Asing agar lebih memudahkan untuk menjalin komunikasi yang baik dengan mitra kerjanya atau rekan-rekan dan media partner lainnya khususnya mitra kerja didunia internasional.

\section{Organisasi Public Relations}

\section{Hubungan Ekdternal}

Hubungan dengan publik diluar perusahaan merupakan keharusan yang mutlak. Karena perusahaan tidak mungkin berdiri sendiri tanpa bekerja sama dengan perusahaan yang lain. Karena itu perusahaan harus menciptakan hubungan yang harmonis dengan publik-publik khususnya dan masyarakat umumnya. Salah satunya dengan melakukan komunikasi dengan publik ekstern secara informatif dan persuasif. Informasi yang disampaikan hendaknya jujur, teliti dan sempurna berdasarkan fakta yang sebenarnya. Secara persuasif, komunikasi dapat dilakukan atas dasar membangkitkan perhatian komunikan (publik) sehingga timbul rasa tertarik.

Public Relation secara Eksternal dalam sistem televisi atau organisasi perusahaan merupakan kegiatan promosi program dalam upaya membentuk persepsi masyarakat atau suatu program yang dikehendaki. Bertemu langsung dengan pers, organisasi komunitas, organisasi profesi. Organisasi sosial, pemerintahan, dan masyarakat umumnya (Aldily 2017).

\section{Hubungan Internal}

Kegiatan Internal Public Relations merupakan kegiatan yang ditujukan untuk publik internal organisasi/perusahaan. Publik internal adalah keseluruhan elemen yang berpengaruh secara langsung dalam keberhasilan perusahaan, seperti karyawan, manajer, supervisor, pemegang saham, dewan direksi perusahaan dan sebagainya.

Hubungan Internal menurut Elvinaro Ardianto dalam (Aldily 2017) adalah kegiata Public Relations untuk membina hubungan dengan public internal, seperti karyawan, para manajemen ,top manajemen dan para pemegang saham agar citra dan repotasi organisasi atau perusahaan tetap positif dimata publik Internal. Melalui kegiatan Internal Public Relations diharapkan dapat memenuhi kebutuhan dan kepentingan publik internal dari organisasi/perusahaan. Dengan hubungan yang harmonis antara pihakpihak yang terkait dalam perusahaan maka akan tercipta iklim kerja yang baik. Dengan begitu kegiatan operasional perusahaan akan berjalan dengan lancar. Kegiatan hubungan internal yang dilakukan oleh seorang Public Relations Officers, yaitu

1. Hubungan dengan karyawan (employee relations). Seorang Public Relations harus mampu berkomunikasi dengan segala lapisan karyawan baik secara 
formal maupun informal untuk mengetahui kritik dan saran mereka sehingga bisa dijadikan bahan pertimbangan dalam pengambilan kebijakan dalam organisasi/perusahaan. Seorang PR harus mampu menjembatani komunikasi antara pimpinan dan karyawan. Karena dengan diadakan program employee relations diharapkan akan menimbulkan hasil yang positif yaitu karyawan merasa dihargai dan diperhatikan oleh pimpinan perusahaan. Sehingga dapat menciptakan rasa memilki (sense of belonging), motivasi, kreativitas dan ingin mencapai prestasi kerja semaksimal mungkin.

2. Hubungan dengan pemegang saham (stockholder relations). Seorang Public Relations juga harus mampu membina hubungan yang baik dengan pemegang saham, serta mampu mengkomunikasikan apa yang terjadi dalam organisasi/perusahaan. Karena sebagai penyandang dana, mereka harus selalu tahu perkembangan perusahaan secara transparan agar dapat meningkatkan kepercayaan mereka terhadap perusahaan. Dengan demikian akan menghilangkan kesalahpahaman dan kecurigaan terhadap perusahaan.

\section{Public Speaking}

Indonesia sendiri, masyarakat cenderung menghargai dan menerima seseorang yang mampu menyampaikan ide-idenya dalam bahasa yang dimengerti oleh publik. Hal ini membuktikan bahwa kemampuan komunikasi, khususnya Public Speaking, menjadi kemampuan yang mutlak harus dimiliki setiap individu agar mampu bersaing di zaman yang semakin dinamis. Menurut Effendy (2006) Public Speaking adalah komunikasi dua arah antara organisasi dengan publik secara timbal balik dalam rangka mendukung fungsi dan tujuan manajemen dengan meningkatkan pembinaan kerjasama dan pemenuhan kepentingan bersama. Gunadi (1998) Public Speaking sebagai sebuah bentuk komunikasi yang dilakukan secara lisan tentang suat hal atau topik dihadapan banyak orang, tujuannya adalah untuk mempengaruhi, merubah opini, mengajar, mendidik, memberi pembelajaran secara jelas serta informasi kepada masyarakat tertentu pada suatu tempat tertentu.

\section{METODE PENELITIAN}

Metode survey eksplanatif (anallitik) digunakan bila periset ingin mengetahui mengapa situasi atau kondisi tertentu terjadi atau apa yang mempengruhi terjadinya sesuatu. Dengan mengambil sempel dari satu populasi dengan mengunakn kuesioner sebagai alat pengumpulan data primer dan survey eksplanatif ini bersifat asosiatif dimana peneliti bermaksud untuk menjelaskan hubungan (korelasi) anatar variabel (Kriyantono 2006).

Penelitian ini dilakukan di Fakultas Ilmu Sosial Dan Ilmu Politik (FISIP) Jurusan Ilmu Komunikasi Universitas Djuanda Bogor, yang beralamat di Jl. Tol Ciawi No. 02 Kota Bogor. Jadwal penelitian yang digunakan untuk penelitian (pengambilan data sekunder dan primer) dilaksanakn selama dua minggu terhitung mulai tanggal 1 Desember 2017 sampai 9 Desember 2017. Dengan mengambil sampel dari satu populasi menggunakan kuesioner sebagai alat pengumpulan data system skoring, dalam penelitian ini skala pengukuran menggunakanWeight Mean Score yaitu dengan pembobotan nilai untuk skala 1-5.

Dalam menentukan jumlah sempel, penulis berpedoman pada pendapat Suharshimi (2006) "Apabila subjeknya kurang dari 100, lebih baik diambil semua, sehingga penelitiannya merupakan penelitian populasi. Tetapi jika jumlah subjeknya besar dapat diambil antara 10- 
15\% atau 20-25\%, 30-35\% atau lebih". Dengan demikian penulis mengambil sempel penelitian ini sebanyak 35\% dari populasi yang ada, yaitu 35\% - $103=66$ orang Mahasiswa semester lima dan tujuh Ilmu Komunikasi Fakultas Ilmu Sosial dan Ilmu Politik Universitas Djuanda Bogor

Penelitian ini digunakan data primer dan sekunder, dimana data primer merupakan data yang diperoleh langsung dari sumbernya, data ini diperoleh dengan menyebarkan kuesioner. Kuesionar menurut Suharshimi (2006) "Pernyataan tertulis yang digunakan untuk memperoleh informasi dari responden dalam arti laporan tentang pribadi atau hal-hal yang ia ketahui". Sedangkan menurut Sugiyono (2008) "Kuesioner merupakan tehnik pengumpulan data yang dilakukan dengan cara memberi seperangkat pertanyaan atau pernyataan tertulis kepada responden untuk dijawab" pada Mahasiswa Ilmu Komunikasi Universitas Djuanda. Selanjutnya adalah data sekunder, data sekunder ini merupakan data yang tidak langsung didapat dari sumbernya, data ini diperoleh dari penelusuran literatur seperti buku-buku, internet, dan sumbersumber pendukung lainnya Pengolahan data penelitian disini dilakukan dengan merekapitulasi terlebih dahulu data yang telah diterima setelah itu hasil tersebut diuji korelasi agar mendapat kesimpulan bahwa signifikan atau tidak signifikan data yang telah diperoleh.

\section{HASIL DAN PEMBAHASAN}

\section{Pengaruh Kompetensi Diri Berbahasa Asing Dalam Menunjang Karir Public Relations}

Public speaking skill merupakan kompetensi yang sangat penting untuk dimiliki. Mereka yang menguasai teknikteknik public speaking akan mampu mempengaruhi khalayak banyak dan membawa perubahan. Seorang public speaker harus mampu mengontrol atensi khalayak dan menyampaikan pesan dengan tepat sasaran
Kemampuan berbahasa asing dalam menunjang karir dibidang public relations sangat dibutuhkan, lantaran bagaimana kecapakapan berpublic speaking dalam mengusai berbicara, menulis, mendengarkan, khususnya menggunakan bahasa asing itu sendiri. Seperti yang dikatakan Ryanto (2011) pentingnya berbahasa asing ketika kita mulai memasuki dunia kerja, khususnya bagi setiap orang yang nantinya akan bekerja dilingkup komunikasi seperti advertising, public relations.

Tabel 1 Korelasi Antara Kompetensi Diri Dalam Menunjang Karir

\begin{tabular}{lccc}
\hline \multicolumn{1}{c}{ Kategori } & \multicolumn{3}{c}{ Tugas Seorang Public Relations } \\
\hline \multirow{2}{*}{$\begin{array}{l}\text { Kompetensi Diri dalam Berbahasa } \\
\text { Asing }\end{array}$} & Korelasi Pearson & Signifikansi & $\mathrm{N}$ \\
\cline { 2 - 4 } & ,403** & 0,001 & 66 \\
\hline
\end{tabular}

Keterangan : **. Hubungan korelasi sangat signifikan pada taraf $1 \%$

Berdasarkan Tabel 1, dapat diperoleh koefisien korelasi rank spearmens hubungan antara kompetensi diri berbahasa asing dalam menunjang karir dibidang public relations sebesar $0,403^{* *}$. Dengan demikian dapat disimpulkan bahwa terdapat hubungan nyata diantara kedua varibel penelitian tersebut berdasarkan interpretasi terhadap koefisien korelasi tingkat hubungannya termasuk pada kategori sedang. Sama halnya dengan Sinatra dan Darmastuti 
(2008) mengatakan bahwa kehadiran public relations sangat dibutuhkan disetiap organisasi. Institusi pada saat ini, tidak terkecuali dalam dunia Perusahaan, terlebih ketika semakin ketat diterapkan disetiap perusahaan di Negara ini. Mau

\section{Kemampuan Pengorganisasian Dalam Menunjang Karir Public Relations}

Kemampuan berbahasa Asing juga sangat diperlukan untuk bersaing di dunia Internasional. Untuk iklan yang berlaku secara global atau dalam skala Internasional. Oleh karena itu seseorang bekerja di bidang Public Relations memerlukan kemampuan bahasa Asing. Pengorganisasian public relations tentunya harus bisa menjalin hubungan yang baik dengan banyak orang dari berbagai belahan dunia dan harus bisa bersikap tidak mau, setiap orang saling berlomba untuk menunjukkan siapa dirinya supaya tetap survive ditengah persaingan yang ada salah satunya dengan kemampuan berbahasa asing.

sopan dan bertutur kata yang baik, karena pekerjaan seorang public relations tentunya berhubungan dengan banyak orang.

Penilaian yang didapat dari sejumlah responden mahasiswa ilmu komunikasi terhadap kemampuan organisasi dalam menunjang karir memiliki tanggapan yang baik dengan kemampuan yang baik pula. Hal ini di dasarkan pada Tabel 2 Perspektif Kemampuan pengorganisasian Public Relations dan kemampuan berbahasa asing.

Tabel 2 Perspektif kemampuan pengorganisasian public relations dan kemampuan berbahasa asing

\begin{tabular}{lccc}
\hline & \multicolumn{2}{c}{ Kemampuan Pengorganisasian Public } & Status \\
Relations & Penafsiran \\
\cline { 1 - 3 } Kemampuan berbahasa asing & Internal & Eksternal & \\
\hline Berbicara & 80 & 78 & Baik \\
Menulis & 82 & 82 & Sangat Baik \\
Mendengar & 82 & 82 & Sangat Baik \\
Membaca & 82 & 82 & Sangat Baik \\
Pengetahuan & 80 & 80 & Baik \\
\hline
\end{tabular}

Keterangan : 1-20 : sangat buruk; 21-40: Buruk; 41-60: Sedamg; 61-80 Baik; 81-100: Sangat baik

Berdasarkan Tabel 2, dapat diperoleh hasil perspektif kemampuan pengorganisasian public relations dan kemampuan berbahasa asing, bahwa yang pertama terdapat kompetensi yang baik dan sangat baik antara kemampuan berbahasa asing dan pengorganisasian public relations baik dalam internal maupun eksternal. Selanjutnya yang kedua adalah terdapat perspektif yang positif dalam kemampuan berbahasa asing dalam hal berbicara, menulis, mendengarkan, membaca dan pengetahuan. Dimana kemampuan ini menunjukkan kemampuan pada bidang internal dan ekternal yang ditunjang oleh kemampuan berbahasa. Seorang public relations harus bisa memiliki kemampuan fasih dalam berbahasa asing agar lebih memudahkan untuk menjalin komunikasi yang baik dengan mitra kerjanya atau rekan-rekan dan media partner lainnya khususnya mitra kerja didunia internasional. Seperti yang diutarakan oleh Syahputra (2014) bahwa bahasa inggris merupakan salah satu di antara bahasa asing yang terdapat 
di indonesia. Bahasa inggris ditetapkan sebagai bahasa asing yang pertama, dalam kemampuan bahasa harus memiliki kompetensi, bahasa berupa mendengarkan, membaca, berbicara, dan menulis.

Tabel 3 Korelasi antara pengorganisasian public relations dalam menunjang karir

\begin{tabular}{lccc}
\hline \multicolumn{1}{c}{ Kategori } & \multicolumn{3}{c}{ Tugas Seorang Public Relations } \\
\hline \multirow{2}{*}{$\begin{array}{l}\text { Kemampuan pengorganisasian public } \\
\text { relations }\end{array}$} & Korelasi Pearson & Signifikansi & $\mathrm{N}$ \\
\cline { 2 - 4 } &, $670^{* *}$ & 0,000 & 66 \\
\hline
\end{tabular}

Keterangan : **. Hubungan korelasi sangat signifikan pada taraf $1 \%$

Berdasarkan Tabel 3, dapat diperoleh koefisien korelasi rank spearmens hubungan antara kemampuan pengorganisasian PR dalam menunjang karir dibidang public relatios sebesar 0,670**. Dengan demikian dapat disimpulkan bahwa terdapat hubungan nyata diantara kedua varibel penelitian tersebut berdasarkan interpretasi terhadap koefisien korelasi tingkat hubungannya termasuk pada kategori Kuat. Seiring berjalan waktu dalam bersaing di Era Globalisasi untuk menguasai bahasa asing membutuhkan berbagai tahapan-tahapan untuk sampai pada tahap menguasai, apalagi di era seperti ini mampu berbicara didepan umum dengan baik dan benar sudah menjadi bagian dari gaya hidup seseorang, sudah saatnya setiap orang yang ingin meningkatkan kualitas hidup, meningkatkan karir, meraih sukses yang lebih tinggi, trampil berbicara didepan umum dan lain sebagainya yang didasarkan oleh kempuan berbahasa asing.

Kemampuan dalam pengorganisasian public relations dalam penyampaian pesan, sehingga mampu meembuat responden yakni Mahasiswa/i Ilmu komunikasi mengeatahui bahwa dengan kemampuan dalam Pengorganisasian public relations dengan baik dapat menunjang karir dibidang public relation, tidak hanya itu responden berpendapat bahwa pengorganisasian public relations harus mampu menguasai berbahasa asing, dimana responden merasa pengorganisasian public relations dengan kemampuan berbahasa asing dapat menjalin hubungan baik dengan berbagai komunitas, mampu menjalin hubungan baik dengan berbagai pelanggan dari berbagai Perusahaan/Organisasi. Angka koefisien korelasi positif menunjukan hubungan yang positif. Seperti yang dikemukakan Ishak (2012) dalam penelitiannya mengemukakan bahwa hubungan yang dibangun didalam semua lapisan, pada kenyataanya memberikan pengaruh yang besar pada oprasional perusahaan tersebut, karena pada kenyataan hubungan yang terjadi didalam organisasi pada akhirnya ditunjukan pada publik diluar organisasi yang bersangkutan. Sehingga organisasi atau perusahaan berhubungan dengan publik yang berada dalam ligkungan eksternal maupun Internalnya nya secara terus menurus. Oleh karena itu kemampuan seseorang dalam public relation untuk mengorganisasikan perusahaan diperlukan dalam membangun citra perusahaan. 


\section{Kemampuan Berbahasa Asing dalam Menunjang Karir Dibidang Public Relations}

Kemampuan berbahasa Asing juga sangat diperlukan bagaimana kemampuan berbicara didepan khalayak. Tidak hanya itu kemampuan berbahasa asing mampu membuat rasa pecaya diri dan rasa nyaman, dalam kemampuan menulis pun dibutuhkan keahlian berbahasa asing, dimana menlis sebuah press release, Opini Public, Artikel membutuhkan keahlian dalam berbahasa asing. Dalam penelitian sebelumnya menjelaskan bahwa mempelajari bahasa asing adalah suatu langkah awal yang baik untuk dapat berkomunikasi dengan orang lain, guna menghadapi tantangan globalisas. Tetapi sekedar mengetahui bahasa orang lain saja tanpa menguasainya dalam komunikasi sehari-hari belum cukup untuk memenuhi kebutuhan globalisasi. Karena di era globalisasi, perkembangan teknologi komunikasi yang sangat cepat menjadikan jarak bukan suatu hambatan untuk mendapatkan informasi dari berbagai penjuru dunia. Dengan demikian semakin jelas bahwa penguasaan bahasa asing merupakan hal yang sangat mendesak, dapat dilihat dari hasil uji korelasi pada Tabel 4.

Tabel 4 Korelasi antara kemampuan berbahasa asing terhadap jenjang karir public relations

\begin{tabular}{lccc}
\hline \multicolumn{1}{c}{ Kategori } & \multicolumn{3}{c}{ Jenjang karir dalam public relations } \\
\hline $\begin{array}{l}\text { Kemampuan berbahasa asing dalam } \\
\text { public relations }\end{array}$ & Korelasi Pearson & Signifikansi & $\mathrm{N}$ \\
\cline { 2 - 4 } &, $652^{* *}$ & 0,000 & 66 \\
\hline
\end{tabular}

Keterangan: **. Hubungan korelasi sangat signifikan pada taraf $1 \%$

Berdasarkan hasil uji korelasi pada Tabel 4, dapat diketahui koefisien korelasi rank spearmens hubungan antara kompensi diri yakini kemampuan berbahasa asing dan kemampuan Pengorganisasian dalam menunjang karir dibidang public relations sebesar $0,652^{* *}$. Dengan demikian dapat disimpulkan bahwa terdapat hubungan yang sangat nyata diantara kedua variabel penelitian tersebut. berdasarkan interpretasi terhadap koefisien korelasi tingkat hubungannya termasuk pada kategori kuat.

Mambaunnisa (2014) kemampuan berbahasa inggris mampu meningkatkan kemampuan seseorang dalam berinterakasi. Sehingga bahasa asing merupakan sebagai kebutuhan. Selanjutnya menurut Yamin (2017) tujuan bahasa asing dalam pembelajaran adalah usaha sadar untuk dapat meningkatkan kemampuan dalam meniti karir sesuai dengan keinginan seseorang. Oleh karena itu, public relations sangat diperlukan baik pada tingkat pemerinahan maupun perusahaan. Public relations diharapkan oleh masyrakat dalam berbagai aktivitas bisa memberikan informasi dengan tujuan bersama, persepsi masyarakat baik itu internal maupun ekternal dalam memandang dan menanggapi berbagai informasi yang terjadi di perusahaan merupakan pandangan umum, disitulah peranan public relations harus memilik strategi dan membiasakan diri dengan berorientasi kemasyarakat agar komuniikasi yang disampaikan tepat pada sasaran yang diinginkan.

Public relations itu sendiri harus memiliki mutu kualitas diri tersendiri. Salah satu mutu kualitas diri ini dengan kemampuannya berbahasa asing, seperti dalam penelitian ini bahwa terdapat hubungan yang sangat nyata terhadap koefisien korelasi tingkat hubungannya termasuk pada kategori Kuat. Sama halnya dengan penelitian sebelumnya yang dilakukan Libero (2013) Mengacu pada era globalisasi sekarang, maka diperlukan alternatif lain metode pembelajaran Bahasa 
Inggris yang lebih praktis dan dapat diakses semua kalangan. Pada sisi lain, kebutuhan mahasiswa terhadap internet menunjukkan trend yang semakin tinggi. Libero menemukan banyak website kursus Bahasa Inggris free online yang menawarkan kemudahan-kemudahan dalam mempelajari bahasa Inggris. Pembelajaran tersebut dapat menghasilkan kualitas diri yang siap memasuki dunia public relations, karena peranan bahasa asing khususnya bahasa inggris kini menjadi peranan penuh bagi seorang public relations.

\section{KESIMPULAN DAN SARAN}

\section{Kesimpulan}

1. Terdapat hubungan antara kemampuan berbahasa asing seseorang dalam menunjang karir di bidang Public Relations.

2. Terdapat hubungan antara kemampuan seseorang dalam pengorganisasian public releations dalam menunjang karirnya kedepan sehingga mampu menempuh jenjang yang lebih baik.

3. Terdapat hubungan antara kompetensi diri seseorang dalam kemampuan berbahasa asing dan pengorganisasian public releations untuk menujang karir.

\section{Saran}

1. Sebaiknya perlu diadakan latihan dan latihan dalam penguasaan bahasa asing oleh mahasiswa baik dalam kelas maupun luar kelas.

2. Sebaiknya perlu dibiasakan dalam setiap pergaulan menggunakan bahasa asing dalam berbicara, membaca, maupun dalam menulis untuk mengasah kemampuan seseorang.

3. Sebaiknya perlu pembelajaran dan praktek penyampaian dengan menggunakan bahasa asing di setiap mata kuliah di program studi ilmu komunikasi.

\section{DAFTAR PUSTAKA}

ldily R. 2017. 101 Amazing public relations ideas. Yogyakarta (ID): PT. Anak Hebat Indonesia

Effendi OU. 2006. Hubungan masyarakat. Bandung (ID) : PT Remaja Rosdakarya.

Gunadi YS. 1998. Himpunan istilah komunikasi. Jakarta (ID) : Grasindo.

Hasan N. 2006. Fullday school model alternatif pembelajaran bahasa asing. Jurnal Tadris 1 (1): 3-11.

Hastuti E, Oswarl T. 2012. Metode pembelajaran bahasa inggris mandiri dengan free visual online course. Jurnal UG 6 (1) : Hal 2-9.
Ishak A. 2012. Peran public relations dalam komunikasi organisasi. Jurnal komunikasi 1 (4): 373-378.

Kriyantono R. 2006. Teknik praktis riset komunikasi. Jakarta (ID) : Kencana, Prenada Media Grup.

Libero H, Prinsip dasar communications Elearning teori dan aplikasinya. Jurnal ternodik 2 (12): 66-69.

Mambaunnisa. 2014. Pengaruh kemampuan berbahasa asing terhadap prestasi belajar siswa. Jakarta (ID): Universitas Islam Negri Syarif Hiyatullah.

Ruslan R. 2010. Metode penelitian public relations dan komunikasi, cetakan lima. Bandung (ID): PT. Rajagrafindo. 
Rumanti AM. 2009. Public relations teori dan politik. Jakarta (ID): Grasindo

Ryanto. 2011. Buku Ajar Metodelogi Penelitian. Jakarta (ID): EDC.

Sinatra L, Dermanstuti R. 2008. Kajian peran public relations dalam meningkatkan citra perguruan tinggi swasta di Jawa Tengah. Jurnal Ilmiah Scriptura 2 (2): Hal 97-107.

Suharshimi A. 2006. Prosedur Penelitian Suatu Pendekatan Praktik Edisi Revisi. Jakarta : Penerbit PT Rineka Cipta.

Sugiyono. 2008. Metode penelitian pendidikan kuantitatif, kualitatif $R \& D$. Bandung (ID) : Alphabeta
Sinaga S. 2010. Potensi dan pengambanan objek wisata dikabupaten tapamuli tengah. Kertas Karya. Sumatera Utara (ID) : Program Diploma Pariwisata.

Syahputra I. 2017. Strategi pembelajaranbahasa Inggris sebagai bahasa inggris sebagai bahasa asing dalam meningkatkan kemampuan berbahasa siswa. Jurnal Penelitian Sosial Keagamaan 17 ( 1 ): 2-10.

Yamin M. 2017. Metode pembelajaran bahasa inggris di tingkat dasar. Jurnal Pesona Dasar 1 (5): 3-11. 
